\title{
Peran Ibu Single Parent dalam Membentuk Kepribadian Anak; Kasus dan Solusi
}

\author{
Warsito Hadi \\ UIN Sunan Ampel Surabaya \\ Email:warsitohadi10@gmail.com
}

\begin{abstract}
Abstrak
Artikel ini menyoal problematika yang dihadapi seorang ibu sebagai orang tua tunggal (single parent) dalam mendidik anaknya. Idealnya, kolaborasi kedua orang tua berperan besar terhadap perkembangan anak. Masalah muncul ketika peran dua orang harus dihadapi oleh seorang ibu yang notabene bukan pemimpin dalam keluarga. Tulisan ini mencoba mengulas beberapa persoalan single parent dalam mendidik anaknya dengan menghadirkan data utama dari wawancara. Penelitian ini berargumen bahwa masalah pada keluarga single parent pada intinya terletak pada kurangnya perhatian dari orang tua. Hal ini melahirkan sikap yang dikendalikan. Solusi untuk masalah ini terletak pada cara menjadi ibu yang baik. Seorang ibu menjadi agen utama yang menciptakan pribadi anak. Oleh karena itu, kesadaran dalam diri orang tua menjadi elemen mendasar yang menentukan kualitas pendidikan di lingkungan keluarga.
\end{abstract}

Kata Kunci: Single Parent, Kepribadian Anak, Psikoanalisis.

\section{Pendahuluan}

Pendidikan pertama dan menjadi fondasi dasar bagi seorang anak adalah pendidikan di lingkungan keluarga. ${ }^{1}$ Dalam sebuah keluarga, ayah dan ibu merupakan unsur pokok. Apabila salah satu dari dua unsur tersebut tidak ada maka sebuah keluarga akan mengalami kegoyahan. Keluarga ideal yakni yang terdiri dari ayah, ibu dan anak-anak. Namun, dalam fenomena kehidupan dalam masyarakat ada yang mengalami ketidaklengkapan unsur dalam sebuah keluarga misal sebuah keluarga yang hanya ada orang tua tunggal yang biasa dikenal dengan istilah single parent. Dalam fenomena ini peran orang tua (ayah dan ibu) akan di jalankan hanya oleh satu orang saja yang tentunya akan mengalami kesulitan dalam menjalankan kedua peran tersebut. Meskipun dengan kesulitan-kesulitan yang dihadapi seorang single parent harus dapat

1 Lihat, misalnya, Mufatihatut Taubah, "Pendidikan Anak dalam Keluarga perspektif Islam", Pendidikan Agama Islam (Journal of Islamic Education Studies), Vol. 3, No. 1 (2015). 
menjalankan peran ganda yaitu sebagai ayah dan ibu bagi anak-anaknya agar keluarganya tidak kacau dan tetap berjalan dengan sebaik mungkin.

Banyak yang menganggap bahwa semua keluarga single parent merupakan broken home (kerusakan rumah tangga). Anggapan seperti itu tentu salah, karena tidak semua keluarga single parent mengalami kerusakan rumah tangga, meskipun kebanyakan memang merupakan bermasalah. Keluarga single parent yang tergolong dalam broken home adalah keluarga yang mengalami masalah-masalah sehingga menjadikan keluarga tersebut rusak, seperti halnya keluarga single parent yang karena keadaan itu anaknya tidak bisa mengontrol dirinya dengan baik sehingga melakukan tindakan-tindakan asusila. Seperti berzina, mengkonsumsi narkotik, hingga ada yang melakukan pembunuhan dan lain-lain.

Poin yang menjadi fokus dalam artikel ini adalah kecenderungan kepribadian anak yang hanya di asuh oleh seorang ibu single parent. Sering kali ditemukan mereka yang hanya di asuh oleh seorang ibu saja akan cenderung kurang bisa menguasai diri dan cenderung salah dalam bergaul. Agar hal-hal tersebut tidak terjadi maka perlu adanya peningkatan peran ibu dalam membentuk kepribadian anak. Pembentukan kepribadian anak paling banyak di pengaruhi oleh pola ibu itu sendiri dalam mengasuh dan mendidik anaknya. Untuk menjadikan pribadi anak yang baik perlu kepribadian yang baik pula dari ibu yang mengasuhnya. Karena ibu merupakan sekolah Pertama bagi anak. Dalam artikel ini akan memberikan petunjuk kepada para ibu, khususnya para ibu single parent bagaimana mendidik anak yang bertanggung jawab (berkepribadian baik).

\section{Peran Ganda Ibu Single Parent dalam Keluarga}

Keluarga merupakan lembaga dasar dari mana semua lembaga sosial lainnya berkembang. Keluarga merupakan kebutuhan utama bagi setiap individu seseorang serta menjadi pusat yang paling penting dalam kehidupan individu seseorang. ${ }^{2}$ Menurut Horton dan Hunt, dalam Layliyah, istilah keluarga biasanya dijadikan untuk merujuk beberapa pengertian yakni: 1). Suatu kelompok yang memiliki nenek moyang

2 Dalam Islam, pendidikan yang utama adalah lingkungan keluarga. Orang tua berkewajiban memberikan arahan, bimbingan dan teladan bagi anak. Mereka adalah sosok yang akan selalu dijadikan rujukan bagi anak dalam menghadapi lingkungan sosial. Baca, Evi Fatimatur Rusydiyah, "Pendidikan Islam dan Kesetaraan Gender (Konsepsi Sosial tentang Keadilan Berpendidikan dalam Keluarga)", Pendidikan Agama Islam (Journal of Islamic Education Studies), Vol. 4, No. 1 (2016). 
sama. 2). Suatu kelompok kekerabatan yang disatukan oleh darah dan perkawinan. 3). Pasangan perkawinan dengan atau tanpa anak. 5). Satu orang baik itu janda atau duda dengan beberapa anak. ${ }^{3}$

Keluarga Single Parent merupakan keluarga yang hanya memiliki orang tua tunggal yakni hanya memiliki ayah atau ibu saja yang bertanggung jawab mengurus anak-anaknya sendiri karena telah berpisah dengan pasangannya baik akibat perceraian, kematian atau melahirkan anak di luar pernikahan. Peran orang tua sangat penting bagi perkembangan pribadi anak, baik dari segi pengasuhan, pendidikan dan lain sebagainya. Pengasuhan yang baik dengan dipenuhi kasih sayang, pendidikan baik mengenai nilai-nilai keagamaan maupun sosial yang diberikan orang tua kepada anak merupakan faktor terbesar untuk menjadikan pribadi anak dan anggota masyarakat yang baik. ${ }^{4}$

Secara umum pengertian single parent yakni orang tua tunggal, yang mana ia harus mengurus keluarganya tanpa bantuan dari pasangan, baik itu suami atau istri. Seorang single parent memiliki kewajiban yang sangat besar dalam mengatur keluarganya. Permasalahan-permasalahan yang timbul dalam keluarga single parent cenderung lebih rumit dibandingkan dengan permasalahan dalam keluarga ideal yang memiliki orang tua lengkap (ayah dan ibu). Orang tua tunggal (single parent) harus bisa berperan ganda yakni menjadi ayah dan ibu bagi anak-anaknya agar keluarganya tetap berlangsung dengan baik. ${ }^{5}$

Status Single Parent merupakan suatu beban yang harus dihadapi oleh seorang istri atau suami yang telah berpisah dengan pasangannya, baik itu karena meninggal atau akibat perceraian. Tidak hanya beban sebagai orang tua single tetapi anak yang berada dalam keadaan tersebut akan cenderung mengalami perubahan sikap, misal awalnya mandiri menjadi manja, yang awalnya periang menjadi pendiam, yang awalnya rajin menjadi malas dan lain sebagainya. Hal tersebut karena sebelumnya ia memiliki orang tua lengkap yang berperan dengan baik dalam kehidupan hingga akhirnya salah satu sosok orang tuanya hilang. Dalam keadaan seperti ini orang tua tunggal harus bisa melengkapi peran yang hilang dengan menjalankan kedua peran yakni menjadi seorang ayah dan ibu bagi anak-anaknya dengan baik dan benar. ${ }^{6}$

${ }^{3}$ Zahrotul Layliyah, "Perjuangan Hidup Single Parent”, Jurnal Sosiologi Islam, Vol. 3, No. 1 (April, 2013), 3.

4 Syamsu Yusuf, Psikologi Kepribadian Anak dan Remaja (Bandung: Remaja Rosdakarya, 2010), 37.

${ }^{5}$ Layliyah, "Perjuangan Hidup", 3.

${ }^{6}$ Yusuf, Psikologi Kepribadian, 37. 
Seorang ibu single parent harus menjalankan dua peran: Pertama, peran sebagai ayah. Seperti yang tergambar dalam kehidupan berkeluarga pada kenyataannya, ayah tidak berperan sebagai pengasuh anak, akan tetapi lebih kepada sibuk sebagai pencari nafkah. Memang sudah kodrat seorang ayah adalah sebagai pencari nafkah, akan tetapi dalam perkembangan anak juga sangat dibutuhkan peran ayah. Di sini ayah harus mengatur dan mengarahkan aktivitas anak, misalnya mengingatkan anak bagaimana menghadapi lingkungan di luar rumah, seperti halnya bergaul, bersosial dan lain sebagainya. Ayah memberi dorongan kepada anak, mengajaknya berkomunikasi, mengajaknya untuk memperhatikan hal-hal di sekitarnya dan juga mengajak berdiskusi mengenai suatu hal dan lain sebagainya. Anak sangat membutuhkan peran ayah bukan hanya sebagai sumber materi akan tetapi anak juga membutuhkan ayah sebagai pengarah dalam kehidupannya. Tugas pokok seorang ayah dalam keluarganya yaitu: sebagai pencari nafkah, sebagai suami yang pengertian dan memberi rasa aman terhadap keluarganya, sebagai pelindung atau tokoh yang tegas, bijaksana dan mengasihi keluarganya. ${ }^{7}$

Bagi anak laki-laki figur seorang ayah akan menjadi panutannya sebagai seorang laki-laki di kehidupannya kelak. Peranan seorang ayah bagi anak perempuan juga sangat penting pada awal masa remajanya dalam mempelajari lawan jenisnya. Anak perempuan yang didampingi ayahnya pada masa tersebut akan dapat memahami bagaimana cara bersikap dan memberi respon terhadap lawan jenisnya. Menurut Ngalim Purwanto dan Sadullah, peranan ayah dalam pendidikan anak-anaknya yakni, sebagai sumber kekuasaan dalam keluarganya, penghubung intern antara keluarga dengan masyarakat atau dunia luar, pemberi rasa aman dan pelindung bagi anggota keluarganya dari dunia luar, sebagai tokoh yang tegas untuk mengadili jika terjadi perselisihan dan juga sebagai pendidik dalam segi-segi rasional.

Kedua, peran sebagai ibu, seorang ibu sangat penting peranya dalam mendidik anak-anak. Ngalim Purwanto mengatakan bahwa sesuai fungsi serta tanggung jawab seorang ibu sebagai anggota keluarga, dapat dijelaskan bahwa peranan ibu dalam mendidik anaknya adalah, sebagai sumber dan juga pemberi kasih sayang, pengasuh dan pemelihara, tempat mencurahkan isi hati, sebagai pengatur dan pembimbing dalam kehidupan berumah tangga atau hubungan pribadi dan sebagai pendidik dalam segi-segi emosional. ${ }^{8}$ Dalam membentuk kepribadian anak, ibu

7 Ema Hartanti, “ Pola Asuh Orang Tua Single Parent dalam Perkembangan Kepribadian Anak di Desa Jetis Kecamatan Selompang Kebupatenn Temanggung" (Skripsi--Institut Agama Islam Negeri (IAIN), Salatiga, 2017), 29.

${ }^{8}$ Ibid., 26-28. 
merupakan figur yang menjadi teladan dan panutan bagi anaknya, jika seorang ibu menghendaki pribadi yang baik dari anaknya maka ibu harus terlebih dahulu mempraktikkan perilaku-perilaku yang baik di hadapan anak dalam kehidupan sehari-hari. Anak tidak akan bersikap jujur, lemah lembut, disiplin dan lain sebagainya jika ibu hanya memberi wawasan mengenai sikap tersebut tetapi dalam kehidupan sehari-hari ibu mempraktikkan sikap yang sebaliknya.

\section{Peran Orang Tua dalam Pembentukan Kepribadian Anak}

Orang tua dalam suatu keluarga sangat dibutuhkan perannya oleh anak, maka dari itu orang tua harus bisa menjalankan perannya dengan sebaik mungkin agar keluarganya dapat berjalan dengan baik. Dalam pembentukan kepribadian anak tentu saja tidak lepas dari peran orang tua, orang tua harus mempunyai prinsip-prinsip tersendiri dalam membentuk kepribadian anak-anaknya. Pembentukan kepribadian anak dapat di capai dengan meningkatkan nilai moral anak dengan cara orang tua harus menerapkan prinsip-prinsip untuk berpikir dan bertindak agar melahirkan perilaku moral yang tinggi dan menuju terbentuknya kepribadian anak yang baik. ${ }^{9}$

Ketidaklengkapan orang tua dalam mendidik anak akan berpengaruh pada karakter anak tersebut, seperti yang dinyatakan oleh Samiyah Hamam seorang pengamat wanita ada beberapa karakter pada anak yang tidak dididik oleh orang tua yang lengkap (ibu dan ayah) adalah sebagai berikut: Pertama, anak tersebut akan cenderung memiliki sifat kecemburuan, pada awalnya anak cemburu pada anak lain yang dapat menikmati kasih sayang dari kedua orang tuanya, hal tersebut masih dalam batas kewajaran. Kemudian kecemburuan tersebut berkembang melebihi kewajarannya, yang kemudian menimbulkan rasa benci, dengki dan lain-lain. Kedua, anak tersebut akan merasa tidak memiliki identitas, apalagi perpisahan orang tuanya adalah karena perceraian. Hal tersebut karena anak akan membagi kasih sayang dan kesetiaan di antara kedua orang tuanya yang sudah berpisah, maka jiwa anak tersebut akan goyah dan merasa seakan-akan kehilangan identitas

${ }^{9}$ Orang tua harus benar-benar memiliki kepribadian yang baik dan mantap dalam hal moralitasnya karena kepribadian anak yang baik akan terbentuk melalui kepribadian orang tua yang baik. Lihat, Hartanti, “ Pola Asuh Orang Tua Single Parent dalam Perkembangan Kepribadian Anak di Desa Jetis Kecamatan Selompang Kebupatenn Temanggung", 73.

El-Banat Vol. 9. No.2 (2019) 305 
pribadinya. Ketiga, akan timbul sikap menutup diri pada diri anak yang hidup bersama ayah atau ibu tiri atau kerabat-kerabatnya yang lain. ${ }^{10}$

Keluarga harus menjadi tempat yang menyenangkan bagi semua anggotanya, termasuk anak. Dalam Islam dianjurkan agar keluarga menjadi tempat pokok dalam mendidik anggota masyarakat dan juga menjadi penyeimbang yang tenang dan damai untuk menjadi tempat tinggal yang menenangkan bagi semua anggotanya. Jika mereka mendapat gangguan di luar, mereka akan berlindung kepada keluarga. Apabila dari salah satu unsur pokok dalam keluarga yakni ayah dan ibu tidak ada, maka keluarga tersebut akan menjadi goyah. Dalam diri seorang anak akan terbentuk kepribadian yang baik melalui keluarga yang ideal. Kepribadian yang merupakan fondasi utama untuk kesuksesan seseorang di dunia dan akhirat. ${ }^{11}$

Perkembangan moral anak banyak dipengaruhi oleh lingkungan di mana ia tumbuh dan berkembang. Tanpa lingkungan masyarakat, kepribadian seseorang tidak akan dapat berkembang, begitu juga aspek moral seseorang. Nilai moral pada anak paling banyak di pengaruhi dari lingkungan luar. Lingkungan ini bisa berarti orang tua, sanak family, teman-teman, guru dan lain sebagainya. Namun, karena pada awal-awal perkembangan anak tidak sepenuhnya tergantung pada orang lain, maka peran orang tua di sini adalah sebagai orang Pertama yang dikenal anak dalam hidupnya untuk mengembangkan moral anak. Anak-anak akan belajar dari orang tuanya bagaimana bersikap dengan orang lain, seperti apa tingkah laku yang baik atau tidak, yang mana yang harus dihindari serta mana yang harus di kerjakan dan lain sebagainya. Bisa dikatakan bahwa orang tua bukan satu-satunya faktor yang memengaruhi terbentuknya kepribadian anak, namun di sini orang tua dapat mengarahkan perkembangan perilaku atau moral anak agar menjadi pribadi yang baik dengan menyadari akan perannya yang besar dalam kehidupan anak. ${ }^{12}$

Berikut ini beberapa sikap orang tua yang perlu diperhatikan dalam mengembangkan moral anaknya: Pertama, konsistensi orang tua dalam mendidik dan mengajakan suatu tingkah laku pada anak. Seperti pada waktu tertentu anak dilarang melakukan tingkah laku ini, maka larangan tersebut harus selalu diberlakukan. Bukan pada suatu saat dilarang dan di

${ }^{10}$ Khatib Ahmad Santhut, Menumbuhkan Sikap Sosial, Moral dan Spritual Anak dalam Keluarga Muslim, terj. Ibnu Burdah (Yogyakarta: Mitra Pustaka, 1998), 22.

${ }^{11}$ Ibid., 23.

12 Singgih D.Gunarsa et al., Psikologi Perkembangan Anak dan Remaja (Jakarta: Gunung Mulia, 2003), 61. 
waktu lain orang tua memperbolehkan. Kedua, sikap orang tua dalam keluarga. Seperti sikap orang tua terhadap saudara-saudaranya, terhadap pembantu rumah tangga, terhadap sopir dan lain sebagainya. Anak-anak akan mengambil contoh sikap orang tua dalam semua hal tersebut setiap harinya, hingga pada akhirnya akan berpengaruh pada perkembangan moral anak. Ketiga, penghayatan orang tua terhadap nilai-nilai agama. Orang tua yang sungguh sungguh menghayati kepercayaannya kepada Tuhan, akan berpengaruh pada tindakan dan sikap mereka sehari-sehari. Seperti cara mengasuh, mengajar dan mendidik anak-anaknya. Anak yang dibekali dengan nilai-nilai keagamaan yang tinggi akan menjadi dasar yang kuat dalam kehidupan mereka di kemudian hari. Keempat, sikap konsekuen dari orang tua dalam menanamkan kedisiplinan terhadap anaknya. Apabila orang tua menghendaki anaknya selalu disiplin dalam berbagai hal seperti ibadah, menjalankan kewajiban dan lain-lain. Maka sikap disiplin tersebut harus ditunjukkan oleh orang tua sendiri dalam kehidupan sehari-hari. Jadi tidak hanya menyuruh anaknya disiplin, tapi orang tua harus terlebih dahulu memiliki sikap disiplin agar anaknya juga disiplin. ${ }^{13}$

Singgih D.Gunarsa menyebutkan bahwa terdapat beberapa cara bagi orang tua untuk menamankan disiplin anak, antara lain yaitu: Pertama, cara otoriter. Pada cara ini orang tua tidak memberi ampun kepada anaknya jika melanggar batasan-batasan atau aturan-aturan yang telah dibuat oleh orang tua. Di sini anak harus patuh terhadap apa yang telah menjadi aturan orang tua, jika anak melanggar aturan tersebut tersbut orang tua akan menghukumnya tanpa ada toleransi sedikitpun. Dalam menerapkan cara ini orang tua menentukan aturan tanpa memperhatikan keinginan-keinginan dan sifat-sifat khusus pada anaknya yang tentunya berbeda dengan anak-anak yang lain. Anak harus patuh dan tunduk terhadap peraturan orang tua. Sikap keras di sini di anggap sikap yang harus diterapkan agar anak-anaknya menjadi penurut, tanpa memperhatikan sisi-sisi lain pada anak. ${ }^{14}$ Dengan cara otoriter, yang dibarengi dengan sikap keras, mengancam, menghukum akan menjadikan anak menjadi penurut, akan tetapi di sisi lain dibelakang orang tua anak cenderung memperlihatkan reaksi-reaksi seperti menolak, menentang karena merasa di paksa. Bisa jadi reaksi penolakan ini di tampilkan dengan tingkah laku- tingkah laku yang melanggar norma-norma dan menimbulkan masalah bagi individu anak dan juga masyarakat sekitar. ${ }^{15}$

${ }^{13}$ Ibid., 62-64.

${ }^{14}$ Ibid., 83.

15 Cara otoriter ini baik dilakukan pada saat anak berada dalam masa awal perkembangannya (masa anak-anak) karena di sini mereka belum bisa menyerap El-Banat Vol. 9. No.2 (2019) 307 
Kedua, cara bebas. Orang tua yang menerapkan cara ini memberikan kebebasan kepada anaknya untuk mencari dan menemukan sendiri tata cara yang memeberi batasan-batasan dari tingkah laku mereka. Orang tua akan bertindak hanya jika tingkah laku anaknya sudah melewati batas normal "keterlaluan". Pada cara ini pengawasan orang tua menjadi longgar dan anak-anak akan terbiasa menentukan sendiri apa yang menutrutnya baik. Di sini orang tua hanya sebagai "polisi" yang mengawasi, menegur dan mungkin memarahi jika terdapat hal yang tidak benar pada anak. Kepribadian anak akan kurang terarah jika orang tua tidak mengarahkannya dengan baik, seperti dalam cara ini hal tersebut yang menjadi kekurangannya. Karena pada anak akan timbul rasa ego yang tinggi sehingga mengalami kesulitan jika harus menghadapi larangan-larangan di lingkungan sosialnya. ${ }^{16}$

Ketiga, cara demokrasi. Pada cara ini sangat memperhatikan dan menghargai kebebasan anak, akan tetapi kebebasan tersebut tidak secara mutlak, kebebasan di sini didampingi dengan bimbingan yang penuh pengertian antara anak dan orang tua. Orang tua akan tetap memperhatikan pendapat anak, jika pendapat tersebut sesuai dengan norma-norma yang ada pada orang tua maka akan disetujui dan jika tidak sesuai maka orang tua akan memberi pengertian kepada anaknya jika hal tersebut perlu diperhatikan lagi apakah baik untuknya atau tidak. ${ }^{17}$ Dengan cara ini akan tumbuh pada anak rasa tanggung jawab untuk memperlihatkan suatu tingkah laku dan akan memupuk rasa percaya dirinya. Ia mampu bertindak sesuai dengan norma-norma yang ada pada dirinya dan mengontrol tindakan mana yang jika ia lakukan orang lain tidak berkenan, ia akan menunda untuk melakukannya.

apa-apa yang baik dan tidak bagi mereka. Cara otoriter masih bisa diterapkan oleh orang tua asal tidak sampai mengganggu perkembangan fisik, mental, kepribadian dari anak itu sendiri. misalnya anak sampai merasa takut untuk berkreasi karena takut mendapat hukuman. Gunarsa, et al., Psikologi Perkembangan Anak dan Remaja, 83-84.

${ }^{16}$ Ibid.

17 Cara demokrasi ini memang paling ideal bagi orang tua dalam menanamkan disiplin pada anak. Akan tetapi tidak menutup kemungkinan kedua cara sebelumnya juga tetap dibutuhkan atau dipergunakan. Hanya saja harus dipertimbangkan kembali cara mana yang harus diprioritaskan dan lebih baik untuk diterapkan pada keluarganya. Gunarsa, et al., Psikologi Perkembangan Anak dan Remaja, 84. 


\section{Konseling Keluarga bagi Ibu Single Parent}

Pembentukan kepribadian anak sangat ditentukan dari bagaimana peran orang tua dalam pola asuhnya. Melaui proses atau pola pengasuhan yang dijalankan, orang tua berupaya mencapai harapannya pada anak dengan berbagai cara. Cara-cara yang digunakan oleh orang tua sangat berkaitan dengan pandangan orang tua mengenai tugas-tugas yang harus dijalankan dalam mengasuh anaknya. Maka dari itu untuk membentuk kepribadian yang baik pada anak maka peran orang tua dalam pengasuhan anak perlu ditingkatkan. Seperti yang telah diketahui bahwa ada beberapa konsep dalam melakukan konseling keluarga, konsep yang digunakan di sini yakni konsep psikoanalisis. Pada konsep ini, mengajarkan bagaimana konselor untuk memahami tentang ketakberfungsian pola-pola keluarga yang telah menyebabkan pribadi-pribadi yang tidak bisa dipecahkan oleh anggota keluarga. Dalam menerapkan konsep ini, konselor akan berusaha membantu anggota keluarga agar menyadari keadaannya dan mengambil tanggung jawab untuk menanggulangi terjadinya masalah-masalah yang mengganggu kelangsungan hidup keluarganya dan juga mengatasi masalah tersebut jika sudah telanjur terjadi. ${ }^{18}$

Pada teori psikoanalisis yang bersumber dari ajaran Freud, memandang bahwa manusia sebagai makhluk yang dikendalikan oleh hati nurani dan sulit kontrol. Maka demikian, agen-agen masyarakat terutama orang tua harus ikut serta dalam membentuk perilaku anak agar memiliki kepribadian yang baik yang tentunya untuk kebaikan individu anak dan masyarakatnya. Kepribadian anak melalui pengembangan moral dapat dibentuk melaui belajar penguasaan diri dan penanaman disiplin. Menurut teori ini, perilaku seseorang termasuk perilaku moral ditentukan oleh tiga faktor yang ada pada diri seseorang itu sendiri yaitu, Pertama yakni Id yang merupakan seseuatu yang ada pada diri seseorang yang mendorong individu untuk berperilaku mengikuti nafsu (animalistik urges and desire), Kedua, ego yang merupakan penentu terbentuknya perilaku riil, Kemudian terakhir yakni, super ego sebagai pengembang elemen pendorong dan berfungsi sebagai agen pengendali yang memberikan pertimbangan pada individu untuk berperilaku salah atau mengontrol apakah perbuatannya itu baik atau tidak. ${ }^{19}$

Dalam penulisan artikel ini penulis telah melakukan penelitian lapangan dengan melakukan wawancara kepada tiga ibu single parent, yaitu ibu Rakhifah, ibu Siti Muthoziah dan ibu Nengka. Hasil dari

18 Faizah Nur Laila, Bimbingan Konseling Keluarga dan Remaja (Surabaya: UINSA Press, 2017), 118-119.

${ }^{19}$ Santhut, Menumbuhkan Sikap, 48. 
wawancara yang dilakukan oleh peneliti, yang akan dideskripsikan dengan penjabaran sebagai berikut: Pertama, penanaman disiplin pada anak. Wawancara Pertama ibu Siti Munthoziah, beliau berumur 51 tahun. tempat tinggalnya di Dusun Tepanas, Desa Kranji, Kecamatan Paciran, Kabupaten Lamongan. Pertama, penulis bertanya "apa nama lengkap ibu dan mohon maaf sebelumnya, suami ibu sudah berapa lama meninggalnya?". Beliau menjawab: "beliau meninggal pada tahun 2004 dan pada waktu itu anak-anak masih kecil-kecil, yang satu masih duduk di bangku SD dan yang satu lagi malah masih TK. Suami saya meninggal karena kecelakaan sepulang kerja". Kemudian penulis bertanya: "bagaimana cara ibu dalam menamkan disiplin pada anak ibu, ketika mereka bermain ke luar rumah misalnya, apa ibu memberi batasan waktu? misal jam segini harus sudah di rumah, atau kalau mereka bermain ibu memberi waktu berapa jam untuk bermain?". Ibu Munthoziah menjawab: "Kalau masalah mereka bermain, saya tidak pernah membatasi, mau mereka bermain sampai larut pun saya tidak melarang, karena anak saya kan laki-laki semua jadi saya rasa mereka bisa menjaga diri sendiri. Tapi kalau sampai tidak pulang ya saya caricari, biasanya kalu anak saya keluar dan mau tidak pulang itu bilang jadi kalu bilang ya saya sudah tidak mencari lagi. Namanya juga anak lakilaki, jarang mau duduk di rumah saja, mesti bermain sama temantemannya. Selama ini ya seperti itu yang saya terapkan kepada anak-anak saya. Karena meskipun saya suruh pulang, kalu masih mau main juga tidak mau pulang, ya sudah saya biarkan asal tidak sampai mengganggu orang lain saja. ${ }^{20}$

Wawancara selanjutnya pada pada ibu Rakhifah di Dusun Tepanas, Desa Kranji, Kecamatan Paciran, Kabupaten Lamongan. Beliau berumur 54 tahun dan suaminya telah meninggal kurang lebih sudah 13 tahun yang lalu, lebih tepatnya pada tahun 2005. Ibu Rakhifah memiliki 6 anak, lima anak laki-laki dan satu anak perempuan. Dua anak laki-lakinya sudah berkeluarga dan yang lain ada yang bekerja dan ada yang masih sekolah. Dalam menanamkan sikap disiplin pada anak-anaknya, di sini penulis mengajukan pertanyaan: apakah ibu memberi batasan waktu bermain kepada anak ibuk?, jawaban beliau: kalau membatasi waktu harus pulang jam berapa, waktu bermainnya berapa jam, tidak. Saya biarkan saja untuk bermain dengan teman-temannya. Saya hanya mengingatkan kalau pulang jangan terlalu malam, tidak baik. Saya menerapkan hal itu pada semua anak saya, tetapi untuk yang anak perempuan saya, lebih saya tekankan lagi dengan memberi ancaman

${ }^{20}$ Siti Munthoziah, Wawancara, Tepanas, 24 November 2018. 
"awas ya kalau pulangnya larut malam, tak kunci pintunya, tidak saya bukain". Untuk anak perempuan saya, lebih saya perketat kalau meminta izin, ketika anak saya meminta izin mau keluar, saya tanya mau kemana tujuannya, sama siapa keluarnya harus jelas, kalau tidak jelas mau kemananya ya tidak saya kasih izin. Dengan cara demikian yang saya terapkan kepada anak-anak saya, alhamdulillah anak saya tidak ada yang terlalu nakal, masih tergolong nurut-nurut sama orang tuanya. Ya nakal sih ada, tapi ya masih sewajarnya tidak sampai keterlaluan. ${ }^{21}$

Wawancara selanjutnya pada Ibu Nengka, berumur 50 tahun. Beliau tinggal di Desa Takerharjo, kecamatan Solokuro, kabupaten Lamongan. Pertama, penulis mengajukan pertanyaan yang sama dengan wawancara-wawancara sebelumnya yaitu nama lengkap dan sudah berapa tahun suaminya meninggal?". Ibu Nengka menjawab: "suami saya sudah meninggal sudah dua puluh tahun an mbak, saya kan punya dua anak laki-laki dan ketika ayahnya meninggal, anak saya yang Pertama sudah agak besar, sudah sekolah di Sekolah Menengah Atas, tapi yang satunya masih duduk di bangku Sekolah Dasar dan yang saya sedihkan ya ini, anak-anaknya belum ada yang jadi orang (belum menikah). Kemudian penulis bertanya lagi: "apakah ibu memberi batasan waktu bermain untuk anak-anak ibu, misal jam sembilan malam sudah harus di rumah apapun alasannya, atau tidak membatasi mereka, atau bagaimna bu?". Ibu Nengka menjawab: "Ya lihat kondisi mbak, kadang ya saya kasih waktu, kadang ya tidak. Biasanya kalu ibu sedang kurang enak badan ya saya batasi, maklum di rumah sepi tidak ada yng menemani. Ya seperti itu yang saya terapkan ke anak-anak saya, tapi ya alhamdulillah, anak-anak saya sudah mengerti keadaan ibunya. Kalau main sama temennya tidak sampai lama-lama, tidak sampai sehari tidak pulang kayak anak-anak tetangga gitu, tapi paling kalo main ya paling lama pagi sampai jam sepuluh siang an sudah pulang, karena biasanya kalau setelah dhuhur saya suruh tidur biar kalau waktunya ngaji sore tidak ngantuk. ${ }^{22}$

Kedua, Pemberian hukuman dan penghargaan. Seperti sebelumnya, wawancara Pertama pada ibu Siti Munthoziah. Dalam hal ini penulis mengajukan pertanyaan yang sama dengan yang di ajukan pada wawancara pada ibu Rakhifah, seperti yang telah dijelaskan di atas, yakni: "apakah ibu menghukum anak-anak ibu jika melakukan sebuah kesalahan?". Ibu Munthoziah menjawab: "kalau menghukum, tidak pernah mbak, biasanya kalu anak saya tidak nurut ya saya marahin gitu saja. Tidak sampai saya pukul, karena saya takutnya kalau sampai saya pukul malah langsung pergi dari rumah dan tidak mau pulang. Dulu pas

${ }^{21}$ Rakhifa, Wawancara, Tepanas, 24 November 2018.

${ }^{22}$ Nengka, Wawancara, Takerharjo, 25 November 2018.

El-Banat Vol. 9. No.2 (2019) 311 
ayahnya masih ada saja pernah di pukul sama ayahnya dan malah pergi ke rumah temennya sampai tidak pulang dua hari. Jadi ya saya tidak mau sampai memukul, toh saya marahin aja anak saya sudah tidak mau ngapain-ngapain, saya suruh apa gitu tidak mau. ${ }^{23}$

Wawancara selanjutnya pada ibu Rakhifah. Pertanyaan yang di ajukan oleh penulis yaitu: "jika anak ibu melakukan kesalahan, misalnya masalah di selokah, nilainya jelek saat ujian. Apakah ibu memberi hukuman, atau bagaimana bu?". Ibu Rakhifah menjawab: "kalau masalah nilainya di sekolah, saya tidak begitu memperhatikan mbak, biasanya anak saya ngasih raportnya ya kalau mau minta tanda tangan aja dan saya juga tidak pernah minta dan saya lihat nilainya, tidak. Tapi kalau mengenai anak saya melakukan kesalahan ya saya tegur, misalnya pernah anak saya bicaranya kurang sopan sama saya. Ya saya bilangin kalau itu tidak baik, bahkan tak marahin kalau sampai tidak sopan sama orang yang lebih tua, sama kakak-kakaknya misal. Kalau dikatakan memberi hukuman atau sampai memukul anak saya, ya belum pernah. Karena alhamdulillah anak-anak saya tidak sampai membuat saya kecewa sampai tega memukul mereka. ${ }^{24}$

Wawancara selanjutnya pada Ibu Nengka, dalam masalah ini, penulis mengajukan pertanyaan: "Apakah ibu Nengka kalau anaknya melakukan kesalahan, ibu menghukum anak ibu, seperti tidak ibu kasih uang jajan, atau hanya memberi mereka teguran atau bagaimana bu ?". Ibu Nengka menjawab: "kalau anak saya sampai melakukan kesalahan, seperti tidak sopan dengan orang yeng lebih tua, terutama sama saya sendiri. Ya tegur mbak, saya marahin. Atau saya diamkan itu anak, dengan saya diam begitu biasanya anak saya ngerti kalau ada yang salah sama dia. Ya alhamdulillah sih, anak saya sudah paham dengan begitu, tidak akan mengulangi kesalahannya lagi. Karena waktu ayahnya masih ada pun juga begitu cara beliau. Alhamdulillah komunikasi saya dengan anak-anak dalam sehari-hari itu terjalin dengan baik, jadi kalau ada apaapa, seperti dia mau apa-apa atau di ganggu temannya di luar gitu langsung bilang sama saya, kadang juga kesalahan dari anak saya sendiri kalau sampai di ganggu temannya begitu. ${ }^{25}$

Kemudian penulis memberi pertanyaan lagi: "kalau anak ibu meraih prestasi di sekolah misalnya, apa ibu memberi hadiah atau memberi pujian, atau bagaimana bu?". Ibu Nengka menjawab: "Pernah sih mbak, waktu anak saya rangking 1 saat kelas 4 sekolah dasar, dia minta belikan sepeda buat sekolah. Ya kebetulan waktunya panen di

\footnotetext{
${ }^{23}$ Munthoziah, Wawancara, Tepanas, 24 November 2018.

${ }^{24}$ Rakhifa, Wawancara, Tepanas, 24 November 2018.

${ }^{25}$ Nengka, Wawancara, Takerharjo, 25 November 2018.
} 
sawah dan saya lagi ada rezeki. Ya saya belikan. Itu dia minta mbak, kalau anak saya tidak minta ya tidak saya beri hadiah. Cuma ya tak pujipuji biar tambah semangat lagi gitu aja, ya Cuma sekali itu mbak waktu dia berprestasi terus saya kasih hadiah. Selanjutnya sampai dia dewasa ya sudah tidak pernah. ${ }^{26}$

Ketiga, penanaman nilai keagamaan. Wawancara Pertama pada ibu Siti Munthoziah, penulis memberi pertanyaan: "Iya ibu, kalau masalah keagamaan, seperti sholat, mengaji, apakah ibu mengajak atau menyuruh anak-anak ibu?". Ibu Munthoziah menjawab: "Kalau masalah sholat, ya saya suruh terus mbak, tapi saya kan sibuk bekerja sih dari pagi sebelum subuh saya sudah sibuk di dapur, buat gorengan, nasi dan lainlain buat saya jual. Jadi kalau watunya sholat ya saya suruh saja, tidak saya ajak jama'ah, tidak sempat. Kalau waktunya mengaji, misal ngaji TPQ (Taman Pendidikan al-Qur'an) sore biasanya ya saya suruh, kalau sempat ya saya antarkan, itu kalau sempat. ${ }^{27}$

Kemudian wawancara selanjutnya Ibu Rakhifah, dalam poin ini penulis mengajukan pertanyaan: "kalau masalah nilai keagamaan, bagaimnaa cara ibu menanamkannya kepada anak- anak ibu, seperti halnya sholat, mengaji, apakah ibu mengajak atau menyuruh anak ibu untuk melakukannya?". Ibu Rakhifah menjawab: "Oh, kalau masalah agama ya harus diutamkan mbak. Ya tentu saya sebagai ibu ya saya suruh, saya ajak jama'ah, kalo saya berangkat jama'ah ke mushola ya saya ajak, kalau sholat di rumah ya saya ajak. Kalau anak saya kemanamana ya yang saya ingetin Pertama ya jangan lupa sholat, atau kalau saya pergi ke luar rumah ya saya pesani jangan lupa sholat ya, begitu. Kalau watunya ngaji, biasanya di desa sini kan ada pengajian al-Qur'an buat anak-anak di mushola, waktu kecilnya anak-anak ya saya antar, ketika sudah mulai besar ya hanya saya suruh. Terutama ketika bulan Ramadhan biasanya kan ada tadarusan di mushola, ya saya ajak selalu. berangkat bareng sama saya. ${ }^{28}$

Wawancara terakhir pada ibu Nengkaa, pada poin ini penulis bertanya: "Iya bu, mengenai penanaman nilai kegamaan pada anka, Apakah ibu juga menyuruh dan mengajak anak-anak ibu untuk sholat, mengaji dan lain-lain?". Ibu Nengka menjawab: "Kalau masalah agama ya nomor satu mbak, saya suruh ngaji, jelas. Kalau waktunya sholat ya saja ajak jama'ah, karena anak-anak saya kan laki-laki ya dua-duanya, ya saya suruh jama'ah di masjid atau di mushola. Kalau tidak begitu ya saja ajak sholat di rumah. Apapun yang berkaitan dengan pendidikan agama

\footnotetext{
${ }^{26}$ Nengka, Wawancara, Takerharjo, 25 November 2018.

${ }^{27}$ Munthoziah, Wawancara, Tepanas, 24 November 2018.

${ }^{28}$ Rakhifa, Wawancara, Tepanas, 24 November 2018.
} 
ataupun pendidikan pengetahuan yang lain ya selalu saya ingatkan. Waktunya belajar ya belajar, waktunya main ya main. Kadang kalu hari libur ya saya suruh bantu-bantu kerjaan di sawah, sama saya. Ibu Nengka menutup wawancara tersebut dengan mengungkapkan: "Buat wawasan. Kebanyakan anak yg sudah di tinggal ayahnya. Jelas sedikit berbeda dg yg masih di samping kedua ortunya. Kebanyakan dari umur yg masih bisa di bilang usia bermain. Anak tersebut mulai berfikir dewasa lebih awal. Berfikir dari segi keuangan. Kelangsungan hidup. Cara dia cari makan. Apa lagi kalau dari keluarga tidak punya. Tapi bisa juga sebaliknya". ${ }^{29}$

Dari hasil wawancara ketiga ibu yang sebagai orang tua tunggal dalam keluarganya, bisa dilihat bahwa mereka memiliki ciri khas masingmasing dalam mengasuh anak-anak mereka. Seperti pada ibu Rakhifah ini termasuk tipe orang tua yang menerapkan cara demokasi, dalam mengasuh anak-anaknya. Di mana ibu Rakhifah dalam mengasuh, beliau tidak terlalu mengekang anak-anaknya, baik dalam waktu bermain dan lain sebgainya. Tapi juga tidak memberi kebabasan yang sebebasbebasnya kepada anaknya. Kadang juga ibu Rakhifah in menerapkan cara otoriter, bisa dilihat dari cara beliau dalam menanamkan nilai keagamaan pada anak-anaknya, sesuai dengan ungkapan beliau bahwa masalah agama harus diutamakan.

Kemudian ibu Siti Munthoziah ini berbeda dengan ibu Rakhifah, ibu ini cenderung lebih memberi kebebasan kepada anak-anaknya. Misal dalam waktu bermain, beliau tidak membatasinya, bahkan kalau tidak pulang ya terserah. Ibu Munthoziah ini merupakan tipe orang tua yang kurang perduli dengan aktifitas anak-anaknya di luar rumah, penulis di sini juga mengamati kehidupan keluarganya. Anak laki-lakinya yang terakhir bisa dikatakan paling kecil, beliau sangat memberi kebebasan pada anaknya ini. Sampai-sampai anaknya ini pernah terjerat kasus NARKOBA. Dengan pola asuh beliau yang memberi kebebasan kepada anaknya ini ternyata berakibat buruk pada tingkah laku anaknya. Meskipun kadang beliau memberi teguran kepada anak-anaknya, tapi kata beliau anak-anak saya yang terakhir ini berbeda sama kakakkakaknya, nakal sendiri. Jadi dia selalu bantah kalau diberitahu.

Untuk yang terakhir, ibu Nengka. Beliau ini termasuk orang tua yang mererapkan cara demokrasi. Di mana ibu Nengka ini memberi kebebasan kepada anaknya, tapi beliau jua membimbing mereka mana yang baik untuk mereka. Dapat lihat dari cara beliau memberi pelajran kepada anak-anaknya, seperti yang sudah dijelaskan di atas, beliau tidak

${ }^{29}$ Nengka, Wawancara, Takerharjo, 25 November 2018. 
terlaku memberi kebabasan kepada anak-anaknya, tidak juga terlalu mengekangnya. Beliau merupakan tipe orang tua yang juga memperhatikan keingininan dari anaknya, bisa dilihat dari cara beliau memberi penghargaan jika anaknya berprestasi.

Berdasarkan pengamatan lapangan yang dilakukan peneliti, bisa disimpulkan bahwa masalah pada keluarga single parent pada intinya sama, anak-anak dalam keluarga seperti ini memang cenderung berbeda dengan anak-anak yang lain, mereka membutuhkan perhatian lebih dari orang tuanya "ibu", karena memang kurangya kasih sayang dan bimbingan kegamaan dan etika dalam suatu keluarga dapat menyebabkan anak mudah terpengaruh dengan lingkungan sekitar terutama teman sebayanya. Tidak sedikit yang ditemukan di lapangan, anak-anak yang menjadi perokok berat, peminum-minuman keras atau masuk dalam pergaulan bebas, karena pengaruh perilaku teman sebayanya. ${ }^{30}$

Jika peran ibu tidak begitu diperhatikan, anak-anak akan tumbuh dengan kepribadian, tingkah laku yang kurang baik, seperti yang terjadi pada keluarga ibu Siti Munthozia. Anaknya ada yang sampai bertindak asusila yakni "terjerat narkoba". Dari hasil penilitian lapangan yang di lakukan dengan wawancara dan sedikit mengamati kelurga ketiga ibu single parent tersebut, bisa dilihat bahwa hal-hal yang tidak di inginkan bisa terjadi karena yang menjadi masalah di sini adalah seorang ibu kurang memahami bagaimana harus menjadi ibu yang baik bagi anakanaknya. Oleh karena itu, di sini peran seorang ibu yang berstatus "single parent" harus digalakkan, dengan apa?. Dengan memberi wawasan kepada ibu dalam keluarga tersebut bagaimana cara mendidik dan mengasuh anak-anaknya sehingga menjadi pribadi yang baik. Seorang ibu juga harus memperhatikan segala faktor yang dapat memengaruhi perkembangan kepribadian anaknya, agar dapat menanggulangi terjadinya hal-hal yang tidak diinginkan. ${ }^{31}$

Dengan merujuk pada teori dan konsep psikoanalisis yang telah dijelaskan di atas, bahwa untuk mengatasi perilaku bermasalah dalam suatu keluarga, maka anggota keluarga lainnya harus ikut berperan nyata agar dapat merubah perilaku tersebut. Maka sebagai solusi untuk kelurga single parent dalam membentuk kepribadian anak, akan dijelaskan mengenai bagaimana cara menjadi ibu yang baik bagi anak-anaknya. Karena kepribadian yang baik dari ibu akan menciptakan pribadi yang baik pula pada anak. Perlu diketahui betapa ampuhnya teladan orang tua dalam membentuk dan memengaruhi sistem nilai dan juga keyakinan pada anak. Pada hakikatnya, orang tua yang mengajarkan suatu sistem

${ }^{30}$ Yusuf, Psikologi Perkembangan, 129.

${ }^{31}$ Santhut, Menumbuhkan Sikap, 48. 
nilai mereka dengan cara hidup dalam sistem nilai tersebut. Misal, orang tua yang ingin mengajarkan anaknya untuk bersikap jujur, maka orang tua harus selalu bersikap jujur dalam kehidupan sehari-hari. Dalam menerapkan proses ini, hubungan atau komunikasi orang tua dengan anak harus terjalin dengan baik. ${ }^{32}$

Menurut Ali Qaimi, agar dalam suatu keluarga anak-anak tidak sampai memilliki tingkah laku yang tidak baik (menyimpang), kurang lebih ada lima hal yang harus diperhatikan oleh seorang ibu yang baik: Pertama, seorang ibu yang baik harus bisa mengenali dirinya dengan sebaik mungkin. Jika seorang ibu dapat mengenali dirinya dengan baik, itu sama halnya mengenal Allah SWT dan jika sudah mengenal Allah SWT dalam jiwanya akan tertancap rasa tanggung jawab akan anakanaknya, Seorang ibu yang bertanggung jawab akan mengutamakan nilainilai keagamaan, kemanusiaan dan hal tersebut akan diterapkan dalam mendidik anak-anaknya. Kedua, Seorang yang baik adalah yang mengerti pentingnya membangun anak-anak yang sholeh sholehah. Dalam membangun anak-anak yang sholehah, tentunya ibu harus terlebih dahulu menjadi sholehah, di sini ibu harus berjuang sekuat tenaga agar keinginannya terwujud. Ketiga, sangat penting bagi seorang ibu untuk memiliki pendidikan yang benar dan sesuai dengan akidah Islam, karena jika seorang ibu memiliki bekal kelimuan yang baik terutama dalam bidang agama, karena dalam mendidik anak-anaknya, seorang ibu perlu belajar dari pengalaman, kebiasaan, tradisi dan lain sebagainya. Keempat, seorang ibu harus memperhatikan aspek agama, etika, moral dan tradisi. karena aspek-aspek tersebut sangat lah erat hubungannya dengan bagaimana cara ia mendidik anak-anaknya. Jika seorang ibu tdak memiliki bekal segala aspek tersebut, bagaimana bisa ia mencetak anakanak yang baik moral dan juga spritualnya. Karena seorang anak yang baik adalah melalui ibu yang baik. Kelima, Seorang ibu harus bisa mengatur rumah tangga dengan keterampilan-keterampilan yang sesuai dan pantas untuk diterapkan dalam mengatur tatanan rumah dengan baik. Dengan penataan yang bagus, rapi dan juga bersih, akan menjadikan anak lebih betah dirumah. ${ }^{33}$

Jika dalam suatu keluarga baru menyadari bahwa keluarganya ini bermasalah saat anak-anak telah tumbuh besar dan telah melakukan hal-

32 Thomas Gordon et al., MOE Menjadi Orang Tua Efektif dalam Praktek, terj. Alex Tri Kantjono Widodo (Jakarta: PT Gramedia Pustaka Utama, 1995), cet. 2, 292.

${ }^{33}$ Anis Choirunnisa, "Peran Ibu dalam Pembentukan Kepribadian Anak Sholeh Menurut konsep Islam" (Skripsi--Universitas Islam Negeri Syarif Hidayatullah, Jakarta, 2013), 16-18. 
hal yang tidak baik, maka orang tua harus bisa berusaha merubah sikap anak yang sudah terbentuk tersebut. Pada tingkah laku anak yang telah tumbuh besar, biasanya tingkah laku tersebut adalah pengaruh dari lingkungan, terutama teman sebayanya (kelompok mereka). Untuk mengubah tingkah laku anak yang tidak dapat diterima (tidak baik) dengan cara mengubah lingkungannya. ${ }^{34}$

Orang tua harus menyadari dan memahami beberapa kiat yang dapat diterapkan dalam keluarga. Menurut penulis, beberapa kiat yang perlu diperthatikan antara lain: Pertama, memperkaya lingkungan (rumah). Yang dimaksud di sini yakni memperbanyak atau menyediakan fasilitas yang di butuhkan anak agar tidak sampai keluar rumah karena mencari fasilitas yang tidak tersedia di rumahnya. Misal, anak anda sering sekali keluar rumah untuk bermain playstasion (PS), yang tentunya dalam tempat bermain tersebut ia akan bertemu dengan teman atau orangorang dengan karakter dan tingkah laku yang berbeda-beda, ada baik dan juga buruknya, orang tua tidak mengetahui. Jika dalam lingkungan tersebut buruk, tentunya akan membarikan dampak negatif pada anak. Maka dari itu alangkah baiknya jika orang tua memberi fasilitas yang dibutuhkan (disukai) anak agar tidak sampai keluar rumah.

Kedua, membatasi ruang gerak anak. Adakalanya anak akan bertingkah laku yang mengganggu lingkungan sekitar (luar rumah) karena orang tua tidak memberi batasan dalam waktu bermain atau ruang gerak pada anak. Misal, anak terlalu lama bermain di rumah tetangga atau temannya, sampai larut malam hingga mengganggu kenyamanan keluarga tersebut. Dengan melihat fenomena seperti ini, maka orang tua harus memberi batasan-batasan pada anak agar tidak sampai mengganggu orang lain.

Ketiga, mempersiapkan anak untuk mengalami perubahanperubahan lingkungan. Misalnya anak anda akan pergi berkemah atau berlibur ke tempat wisata atau akan memasuki sekolah baru, tentunya anak akan berkenalan dengan teman-teman baru, suasana baru dan lainlain yang berbeda dengan sebelumnya. Selaku orang tua, anda bisa mempersiapkan anak untuk menghadapi lingkungan baru tersebut, misal memberi pengertian bahwa memilh teman itu perlu dan sangat penting karena dengan teman yang baik kita akan ikut baik dan begitupun sebaliknya. Sehingga jika nantinya terjadi hal yang tidak benar, anak akan langsung menyampaikan kepada orang tua secara transparan (terus terang), kemudian orang tua bisa memberi solusi atas hal tersebut.

34 Thomas Gordon, Menjadi Orang Tua Efektif, terj. Farida Lestari Subardja et al. (Jakarta: PT Gramedia Pustaka Utama, 1996), cet. 11, 115.

El-Banat Vol. 9. No.2 (2019) 317 
Keempat, bersama-sama (orang tua dan anak) membuat rencana untuk memperbaiki atau melakukan suatu hal. Di sini orang tua mengajak anak untuk berdiskusi. Misal, orang tua akan pergi keluar kota, maka beritahulah anak anda satu minggu sebelum berangkat mengenai hal-hal yang harus dikerjakannya selama orang tua tidak ada, batasan waktu bagi anak dan semisalnya dan mendiskusikannya dengan anak. Agar anak dapat melakukan kegiatan-kegiatannya dengan baik. Dalam hal lain, misal seorang anak remaja harus mencuci pakaiannya sendiri, menyetrika, merapikan dan semisalnya, maka usahakan fasilitas yang dibutuhkan anak sudah tersedia.

\section{Kesimpulan}

Dalam keluarga yang hanya memiliki orang tua tunggal (single parent) maka orang tua di sini harus bisa berperan ganda, yakni memenuhi tanggung jawab seorang ayah dan ibu bagi anak-anaknya. Hal inilah yang biasanya memicu ketidakharmonisan atau ketidakstabilan keluarga jika seorang single parent ini gagal dalam menjalankan perannya. Anak-anak yang tidak di asuh oleh orang tua yang lengkap, dalam kasus ini hanya di asuh seorang ibu saja, cenderung lebih susah di atur dan tidak memperdulikan keadaan orang tua "ibu" nya. Untuk mengatasi ketidakstabilan dalam keluarga, maka seorang ibu single parent harus bisa menjalankan perannya dengan baik dan benar. Agar seorang ibu tidak salah dalam mengasuh dan mendidik anak-anaknya, ada beberapa hal yang perlu diperhatikan: 1). Pendidikan ibu sangat penting, dengan bekal ilmu, wawasan, serta pengalaman yang luas akan menjadikan ibu lebih dapat menyesuaikan cara mendidik dan mengasuh anak dengan baik. Pendidikan menjadi penting karena anak yang unggul terbentuk dari ibu yang unggul. 2). Orang tua, terutama seorang ibu merupakan guru Pertama untuk anaknya, maka jika ibu menghendaki anak-anaknya tumbuh dengan pribadi yang baik, seorang ibu harus terlebih dahulu memiliki pribadi yang baik. 3). Dalam pertumbuhan anak, aspek-aspek agama, moral, etika, sosial/tradisi perlu diperhatikan, karena semua aspek tersebut sangat erat hubungannya dengan pembentukan kepribadian anak. 4). Komunikasi orang tua dan anak harus terjalin dengan baik, misal, orang tua sering mengajak diskusi anak-anaknya mengenai hal yang dilakukan anak tersebut baik atau tidak. Dengan komunikasi yang terjalin dengan baik, anak akan lebih transparan pada orang tua, misal ia mengalami gangguan di luar ia langsung meminta pendapat orang tua. 5). Pembatasan gerak bagi anak perlu diterapkan agar anak tidak sampai bertindak negatif dan mengganggu lingkungan sekitar. 


\section{Daftar Rujukan}

Choirunnisa, Anis. "Peran Ibu dalam Pembentukan Kepribadian Anak Sholeh Menurut konsep Islam". Skripsi--Universitas Islam Negeri Syarif Hidayatullah, Jakarta, 2013.

Gordon, Thomas et al. MOE Menjadi Orang Tua Efektif dalam Praktek, terj. Alex Tri Kantjono Widodo. Jakarta: PT Gramedia Pustaka Utama, 1995.

Gordon, Thomas. Menjadi Orang Tua Efektif, terj. Farida Lestari Subardja et al. Jakarta: PT Gramedia Pustaka Utama, 1996.

Gunarsa, Singgih D. et al. Psikologi Perkembangan Anak dan Remaja. Jakarta: Gunung Mulia, 2003.

Hartanti, Ema. "Pola Asuh Orang Tua Single Parent dalam Perkembangan Kepribadian Anak di Desa Jetis Kecamatan Selompang Kebupatenn Temanggung". Skripsi--Institut Agama Islam Negeri (IAIN), Salatiga, 2017.

Laila, Faizah Nur. Bimbingan Konseling Keluarga dan Remaja. Surabaya: UINSA Press, 2017.

Layliyah, Zahrotul. "Perjuangan Hidup Single Parent”, Jurnal Sosiologi Islam, vol. 3, no. 1. April, 2013.

Rusydiyah, Evi Fatimatur, "Pendidikan Islam dan Kesetaraan Gender (Konsepsi Sosial tentang Keadilan Berpendidikan dalam Keluarga)". Pendidikan Agama Islam (Journal of Islamic Education Studies), Vol. 4, No. 1 (2016).

Santhut, Khatib Ahmad. Menumbuhkan Sikap Sosial, Moral dan Spritual Anak dalam Keluarga Muslim, terj. Ibnu Burdah. Yogyakarta: Mitra Pustaka, 1998.

Sjarkawi, Pembentukan Kepribadian Anak (Peran Moral Intelektual, Emosional dan Sosial Sebagai Wujud Intelegensi Membangun Jati Diri). Jakarta: PT Bumi Aksara, 2006.

Taubah, Mufatihatut, "Pendidikan Anak dalam Keluarga perspektif Islam". Pendidikan Agama Islam (Journal of Islamic Education Studies), Vol. 3, No. 1 (2015).

Yusuf, Syamsu. Psikologi Kepribadian Anak dan Remaja. Bandung: Remaja Rosdakarya, 2010. 
Munthoziah, Siti. Wawancara, Tepanas, 24 November 2018.

Nengka, Wawancara, Takerharjo, 25 November 2018.

Rakhifa, Wawancara, Tepanas, 24 November 2018. 